\title{
Jackfruit seeds and its physical properties
}

\section{Ankur M. Arya, B.R. Singh, Samsher, Suresh Chandra, Neelesh Chauhan, Vaishali and Sweta Singh}

See end of the Paper for authors' affiliation

Correspondence to :

\section{Ankur M. Arya}

Department of Agricultural Engineering,

SardarVallabhbhai Patel University of Agriculture and Technology, Meerut (U.P.) India

Email: arya.ankur76@gmail. com
-ABSTRACT : The physical properties of jack fruit seed are essential for the design and facilities for the harvesting handling conveying, separation, drying, aeration, storing, and processing. Various types of cleaning, grading and separation equipments are designed on the basis of their physical properties. The length came between $22.06 \mathrm{~mm}$ to $35.68 \mathrm{~mm}$. whereas the width was ranged between $10.66 \mathrm{~mm}$ to $21.78 \mathrm{~mm}$. The thickness was in between $8.72 \mathrm{~mm}$ to $16.50 \mathrm{~mm}$. The arithmetic mean diameter of jackfruit seed were ranging from $15.02 \mathrm{~mm}$ to $23.80 \mathrm{~mm}$. The geometric mean diameter was $13.30 \mathrm{~mm}$ to $22.61 \mathrm{~mm}$ and the sphericity was found between 0.53 to 0.73 . The jackfruit seed showed bulk density as $0.49 \mathrm{~g} / \mathrm{ml}^{3}$. Whereas the true density was lying between 1.02 $\mathrm{g} / \mathrm{ml}^{3}$ to $1.59 \mathrm{~g} / \mathrm{ml}^{3}$, while porosity came as 50.27 to 69.17 per cent.

- KEY WORDS : Jack fruit seed, Physical properties, Length, width, Thickness, Arithmetic mean diameter, Geometric mean diameter, Sphericity, Bulk density, True density, Porosity

- HOW TO CITE THIS PAPER : Arya, Ankur M., Singh, B.R., Samsher, Chandra, Suresh, Chauhan, Neelesh, Vaishali and Singh, Sweta (2020). Jackfruit seeds and its physical properties. Internat. J. Agric. Engg., 13(1) : 96-99, DOI: 10.15740/HAS/IJAE/13.1/96-99. Copyright@ 2020: Hind AgriHorticultural Society. 